\title{
Current Situation and Difficulties of Virtual Practice Teaching of Ideological and Political Courses in Universities under the Background of "Internet +"
}

\begin{abstract}
Ying Wan ${ }^{1, a}$
${ }^{1}$ Jiangxi Vocational Technical College of lndustry \& Trade, Jiangxi, Nanchang, 330038

a739960103@qq.com

ABSTRACT

With the help of modern information technology, the implementation of virtual practice teaching is the exploration of Ideological and political course teaching innovation. In the process of promoting the close connection between information technology and ideological and political education, there are some defects: teachers do not have a clear understanding of the virtual practice teaching of Ideological and political education, virtual practice teaching resources have not been fully excavated and sorted out, and the standardization of virtual practice teaching is poor. Therefore, colleges and universities should strengthen Internet thinking and deepen teachers' learning concept; To explore the cooperation between school and enterprise, to organize and excavate the virtual practice resources; Design practice teaching plan, enhance the standardization of virtual practice teaching, realize the integration of virtual and real practice teaching of Ideological and political course, and enhance the results of practice education.
\end{abstract}

Keywords: Internet era, College Ideological and political course, Virtual practice teaching

\section{高校思政课在 “互联网+”背景下的虚拟实践教学现状 及困境}

万颖 1 , a

${ }^{1}$ 江西工业贸易职业技术学院 江西 南昌 330103
${ }^{a} 739960103 @ q q . c o m$

摘要:

借助现代信息技术实施虚拟实践教学是思政课程教学革新的探究。在促进信息技术和课程思政教学紧密联系 的过程中, 出现了以下几点缺陷: 教师没有清楚了解思政课虚拟实践教学、虚拟实践教学资源还没有得到完 全挖掘和整理、虚拟实践教学规范性差。所以, 高校要增强互联网思维, 加深教师的学习观念; 开拓校校合 作和校企合作, 整理并挖掘虚拟实践资源; 设计实践教学规划, 增强虚拟实践教学的规范性, 实现思政课实 践教学的虚实融合, 增强实践育人成果。

关键词: 互联网时代; 高校思政课; 虚拟实践教学

\section{1. 虚拟实践教学的认识}

\section{1. 虚拟实践教学的内涵}

虚拟实践是一种依据计算机、网络和虚拟现实的 一种新型信息技术, 也是一种能在电脑网络空间中规
划和探究虚拟客体的客观运动。虚拟实践的本质是主 客体借助数字化中介体系在虚拟空间实施的双向对象 化运动。同时虚拟实践是社会物质实践的一种派生物 质, 具备相对独立性。且虚拟实践相对独立, 和现实 实践密不可分、互相影响, 一同促进人类社会共同进 步。 
思政课程的一种实践教学方式之一就是虚拟实践 教学。教师依据课程思政实践教学规划, 有规划的、 系统让学生借助互联网思维在网络虚拟空间实施的不 同种类的实践教学活动。在思政课教学实践中, 虚拟 实践教学不能完全占据整个课堂。虚拟实践教学作为 弥补现实实践教学的工具, 要将现实实践教学和虚拟 实践教学各自的优点都发挥出来, 才能使得网上教学 和线下教学、现实实践和虚拟实践互相作用, 将思政 课程时间教学的作用发挥到最大。

\section{2. 虚拟实践的层次区分}

互联网技术和绘图能力不断提高, 现实世界和虚 拟技术的界限越来越模糊, 过去的虚拟技术是局限于 视觉, 而现在已经扩展到身体和心灵都能参与进来, 虚拟技术也逐渐多维度发展，有了巨大的推进。其实， 现在的虚拟技术有三种深度, 其一是仅仅局限在电子 产品的二元空间进行体验, 我们熟知的办公软件, 上 网查找资料都是这种技术的延伸。其二是在电子产品 的屏幕上显示 $3 \mathrm{~d}$ 环绕的形象来进行工作, 给人一种更 加真实的体验感, 例如网络动画, 网络游戏等立体作 品。其三是这几年的新型技术一一VR。他的真实性远 远超过以上两种, 他需要专业的设备和特定的环境来 和人合作, 让人感觉到好像处于真实的的世界中, 人 们可以在里面体验飞行驾驶, 或者去遥远的地方参观。 虚拟技术的这三个方面, 是虚拟技术从旧到新的发展 成果, 每个方面都有适合的工作, 深刻把握这三个方 面可以促进以后虚拟现实的进步。

\section{2. “互联网” 时代高校思政课虚拟实践教学 的意义}

高等院校思想政治教育和网络技术的联系越来越 紧密, 课堂教学时也应该加大虚拟技术应用的的比例, 这可以为思政教育注入新鲜活力。首先教师需要紧跟 时代发展的潮流, 不断调整完善自身的教学方式, 在 思政课堂上充分发挥出互联网技术的价值, 通过使用 互联网技术来拓展学生的视野, 使学生可以更加深入 地了解社会发展的实际状况, 以此来提高学生的逻辑 能力和思维能力, 使学生可以在交流思考中提高自身 的综合能力; 其次学校也需要紧跟时代发展的潮流, 不断改革自身的教育机制, 建立起完善、规范的教育 体系, 将虚拟实践教学与思政教育有效结合在一起, 以此来提高学生思政素养和实践能力; 最后高校和教 师在开展教学时还需要关注学生的心理活动, 引导学 生树立起正确的三观, 现阶段互联网技术不断发展, 学生在生活和学习过程中也会受到互联网技术的影响, 但由于学生的思想观念还不够成熟, 学生很容易受到 不良信息的影响, 这些不良信息都会对学生的身心健 康产生不良的影响。

现在, 互联网发展的越来越迅速, 网络上有各式 各样的信息, 很多大学生沉溺网络不能自拔, 沉浸在 虚拟世界中忽视了现实生活, 导致学习成绩下降严重, 更有甚者有可能接触违法犯罪活动, 最终毁了自己的 一生。如果我们把这种虚拟技术放到课堂中来, 让学 生们能够拥有更强的思想力量来控制自己, 合理上网
拒绝沉迷，让学生在提高思想政治层次的同时，拒绝 不良网络信息的吸引, 提高学习和解决问题的能力, 完善思想政治的武器。

\section{3. 高校思政课虚拟实践教学的现状及困境}

\section{1. 高校思政课虚拟实践教学的进展现状}

现阶段随着思政教育的不断创新，虚拟实践教学 在高校思政教育中占据着十分重要的位置，它不仅将 互联网技术与思政教育有效结合在一起，还提高了学 生的思政素养和实践能力。基于虚拟实践教学和思政 教育的重要性, 高校需要认识到两者的价值, 不断加 深两者的融合程度。

如今, 高校思政教学进行了虚拟性的实践教学, 其中主要是有效应用了媒体教育资源的多样性, 并且 进行了专业化的学习、问卷调查、主体团课学习等多 种教学活动。第二种虚拟实践主要是以互联网教育类 游戏软件与具有教育意义的互联网展览、互联网收藏 馆、互联网纪念店等为主体进行教学。第三种虚拟实 践主要是创建互联网教学平台, 将思政课堂实践和虚 拟技术相结合。部分高校还创造了数字化的互联网教 学平台, 例如: 革命收藏馆、长征文化馆等。第一种 和第二种虚拟实践在开展活动十分依赖公共互联网, 它不仅可以丰富活动的信息资源, 还可以实现信息共 享, 使教学可以更加顺利地开展, 所以高校在开展教 学时经常采用这两种方式。第三种虚拟实验需要依赖 于虚拟现实技术，它需要技术先进的设备和软件。

\section{2 高校思政课虚拟实践教学的现实困境}

\subsection{1. 教师对思政课虚拟实践教学的认识不 足}

现阶段教师在开展思政教学时还存在一些不足, 教师不能真正认识到实践教学的重要性, 无法通过课 堂教学提高学生的实践能力, 教师需要不断调整自身 的教学方式, 改变自身错误的教学理念。所以, 部分 老师坚持传统的思政教学模式,一味的排挤虚拟实践 教学手段。除此之外, 教师对于虚拟实践的了解较少 也致使了他们把思政课堂虚拟实践教学和互联网思政 教学看作一体。尽管思政课虚拟实践教学主要是运用 互联网技术，但是它的执行重心、作用影响、秩序规 则和互联网思政教学完全不一样, 因此二者之间是不 可以一概而论的。

\subsection{2. 思政课虚拟实践教学资源缺少科学合 理的完善}

虽然思政课虚拟实践教学资源较多，但是缺少了 科学合理的总结。高校的思政课虚拟实践教学仍然会 出现老师 “个人为主、孤军奋战 “的情况, 高校对于 思政课虚拟实践教学的发展也缺少了良好的合作氛围。 同时只有少数高校思政课堂教学网站拥有独立的虚拟 实践教学区域, 尤其是全国性、国际性的教学平台仍 
然没有创建, 从而使思政课虚拟实践教学资源缺少科 学合理的总结完善。

\subsection{3. 思政课虚拟实践教学缺少系统化的管 制}

在教学过程中，虚拟实践随着时代的发展应运而 生, 和传统的实践教学相比较, 虚拟实践教学缺少了 完整的管制系统。在开展实践活动时, 在 “重视现实 实践, 忽略虚拟实践”观念的影响之下，部分教师在 开展实践教学活动的时候, 没有把虚拟实践融入到教 育大纲以及计划当中, 在虚拟实践教学的组织形式、 内容以及考核方法中没有形成系统化的设计与规划, 有着较强的随意性, 导致虚拟实践的教学形式比较繁 杂, 内容比较丰富。教师在进行虚拟实践的过程中, 一般只关注到了对虚拟实践教学内容方面的构建, 针 对虚拟实践的教学过程, 没有实现有效化的监控与指 导。除此之外, 因为虚拟实践一般都是在虚拟空间中 开展, 针对于虚拟教学活动过程中出现的问题以及困 惑, 教师无法及时地予以回复。以上这些问题便导致 虚拟实践教学容易偏向形式化, 无法充分发挥原本具 有的育人作用。

\section{4. 高校思政课虚拟实践教学的对策建议}

\section{1. 强化互联网思维, 进一步更新教师教学 理念}

老师的教学观念和老师的教学行为息息相关, 是 否拥有时代理念的教学观念对于教学行为能否可以和 时代发展相符合起到了决定性作用。现阶段, 在互联 网快速发展的背景下, 因为互联网本身是传播资讯与 信息的新媒体, 已经成为学生共享与沟通信息的重要 平台之一。因为学生网络群体非常庞大, 所以教师一 定要完善教学观念, 创新思维定势, 在理解实践概念 的方面, 也要及时融入新的时代内涵。所以, 一方面 教师应该很好地继承传统的实践教学形式, 另一方面 还要积极地迎合信息化时代提出的要求, 深度运用互 联网思维, 并且将它更好地渗透进教育之中, 在开展 思政课虚拟实践教学的过程中要重视创造性的融入, 更好地迎合学生个性化、多样化的需求。

\section{2. 加强校校合作、校企合作，进一步整合 与开发虚拟实践资源}

第一，打造思政课虚拟实践的实践教学平台。在 实践教学平台中, 虚拟实践教学版块在内容部分实现 了集主题展览馆、主题纪录片、网上博物馆、网上世 博会、网上经典诵读、网上纪念馆以及电子游戏等的 一体化, 并且每隔一段时间便定期对实践资源进行更 新; 在功能部分, 实现了教学过程的沟通与讨论、实 践教学内容的发布、实践成果的展示、实践痕迹的大 数据管理、分数的记录以及查询等的一站式服务。

第二，合理应用并且开发思政课的教学网络游戏。 现阶段, 在网络技术快速发展的背景下, 各类网络游
戏不断出现。对于教师来说, 要把互联网应用于教育 教学实践中, 把网络游戏融入到思政课实践教育活动 中, 达到教学目的和任务。比如教师通过开展 “榫卯” 和 “折扇” 等相关游戏, 让学生从中学习工匠精神, 提升教学实践的育人水平和能力。针对条件比较好的 高校, 在教学实际需求的基础上, 开发一些网络游戏, 以此来帮助开展思政课教学。

第三，建设虚拟实践教育教学场地。在建立虚拟 实践教学场地的基础上, 给学生营造一个良好的、交 流的三位虚拟实践氛围, 解决社会实践不能达到全员 覆盖的目的这一问题。虚拟实践教学场地, 将虚拟现 实技术和计算机网络技术相互融合，突破时间和空间 的制约，模拟自然景观、历史事件以及爱国主义场所 等, 进一步建设三维虚拟环境, 同时依靠不同种类的 传感器和可视化工具, 让人们从视觉、听觉以及触觉 等方面深层次地感受虚拟环境, 增强学生的参与程度 和积极程度, 达到实践教学的任务和目的。

\section{3. 制定实践教学大纲, 进一步规范虚拟实 践教学管理}

虚拟实践是一种规范程度的教学环节, 要想确切 地制定虚拟实践教育的目的和任务、教学时长、教学 方法、教学具体安排、教学开展方式以及考察方式等 问题, 就要把虚拟实践融入到课程实践教学的学习任 务中, 对虚拟实践教学相关活动的开展进行合理的规 范, 让虚拟教学实践活动可以顺利进行, 提升实践教 学的规范程度和效率程度。

\section{5. 结论:}

综上所述, 在思政课实践教学过程中, 虚拟实践 教学是一种全新的数字化和虚拟化教育教学方式, 突 破了各种方面的制约，比如人力、物力自己时间空间 等方面, 让高校思政课实践教育教学从 “平面” 向着 “立体”的方面发展、从“传统” 向着 “现代” 的方 面发展、从“网下” 向着 “网上” 的方面发展, 让思 政课教学的育人能力得到全面和深层次地提升。

\section{REFERENCES}

[1] Xia Xiaojing, Hu Ying. Design and implementation of online assessment system for practical training based on virtual reality technology _ taking comprehensive skill training course of pharmaceutical preparations as an example $[\mathrm{J}]$. China modern educational equipment, 2014 (11): 119-121

[2] Luo Lufeng, sun Shuang, Li Guoqin, Yang Hui. Research on the application of virtual reality technology in skill training teaching evaluation $[\mathrm{J}]$. China modern educational equipment, 2016, 0 (21): $89-91$ 
[3] Cai Bao, Gu Hongliang, sun zhangchi, Zhu Wenhua. Research on the application of virtual reality technology in practical teaching in Colleges and universities $[\mathrm{J}]$. China educational technology equipment, 2019, 0 (4): 49-51

[4] Liu Xiulun, Cheng Li. Reflections on the multi dimensional teaching mode of Ideological and political theory course in Colleges and Universities _ Taking Chongqing University of Posts and Telecommunications as an example [J]. Journal of Chengdu University: Social Science Edition, $2018, \quad 0$ (2): $110-115$

[5] Liao Yuewen. To ensure that every college student can participate in social practice _ Investigation and Research on College Students' full participation in social practice work $[\mathrm{J}]$. Journal of Ideological and theoretical education, 2011 (1): 111-115

[6] Liu Xiaoyu. The development of virtual world and the expansion of teaching content of "Introduction to basic principles of Marxism" [J]. Research on Ideological and political education, 2014 (1): $71-73$

[7] Chang Qing. Philosophical thinking of Ideological and political education in Colleges and Universities under the virtual environment — Realistic Consideration of network virtual reality technology [J]. Legal system and society, 2011 (17): $234-235$

[8] Dong Jinquan. Significance and possibility of VR based virtual practice teaching of Ideological and political theory course in Colleges and universities [J]. Journal of Chongqing University of science and Technology (SOCIAL SCIENCE EDITION), 2011 (8): $155-156$

[9] Zhou Liangfa, Han Jianchen. Construction and application of virtual practice teaching mode of Ideological and Political Theory Course Taking the course of introduction to Mao Zedong Thought and theoretical system of socialism with Chinese characteristics as an example [J]. Journal of Qilu Normal University, 2017, 32 (2): $61-65$

[10] Jiang Kening, Hao Xinchun. Analysis on the improvement path of practical teaching of Ideological and political theory course for Undergraduates — Taking Zhongnan University of economics and law as an example [J]. New Campus: shangxunjiao, 2017, 0 (5): 148 149
[11] Guo Haicheng. Application and Prospect of new media and new technology in Ideological and political theory teaching in Colleges and Universities — Taking "rain classroom" as an example $[\mathrm{J}]$. Journal of Heilongjiang Institute of education, 2018, 37 (2): 42-44

[12] Huang Donggui, LV Xiaofeng. Analysis on the combination mode of new media, new technology and ideological and political theory classroom Taking "mobile phone phenomenon" in Ideological and political classroom as an example [J]. Journal of Nanchang Normal University, 2018， 39 (2): $71-74$

[13] Huang Zhenxuan. Construction of mobile network classroom of Ideological and political course in Colleges and universities in the "Internet + " era $[\mathrm{J}]$. Journal of Guilin Teachers College, 2018, 32 (3): $48-50$

[14] Wang Fuqiang, Li Tao, Wei Dan, Li Yanan. The specific form and theoretical basis of the integration of Ideological and political education and new media technology for college students [J]. Journal of Chongqing Institute of industry and trade, 2017 , 0 (1): $21-24$

[15] Lu Jing. Teaching reform practice and rational thinking of the application of new media in Ideological and Political Teaching — Taking the teaching app "Zhongcheng smart classroom" as an example $[\mathrm{J}]$. China educational technology equipment, 2018, 0 (4): 108-110 